Çukurova Üniversitesi Mühendislik Mimarlık Fakültesi Dergisi, 35(3), ss. 631-645, Eylül 2020

\title{
Yıllık Pelinotunun (Artemissia annua L.) Kimyasal Kompozisyonu ve Antioksidan Kapasitesinin Belirlenmesinde Sub ve Süperkritik Akışkanların Etkisi
}

\author{
Murat TÜRK ${ }^{* 1}$, E. Sultan GIRAY ${ }^{2}$ \\ ${ }^{1}$ Cukurova Üniversitesi, Ceyhan Meslek Yüksekokulu, Ceyhan, Adana \\ ${ }^{2}$ Çukurova Üniversitesi, Fen Edebiyat Fakültesi, Kimya Bölümü, Adana
}

Geliş tarihi: $18.09 .2020 \quad$ Kabul tarihi: 23.10 .2020

Öz

Bu çalışmada, tıbbi aromatik bitkilerden yıllık pelinotunun (Artemisia annua L.) kimyasal kompozisyonu ve antioksidan aktivitesi üzerine sub ve süperkritik akışkan ekstraksiyon metodlarının etkileri incelenmiştir. Uygulanan sub/süperkritik akışkan ekstraksiyonları, subkritik su, subkritik etanol ve süperkritik $\mathrm{CO}_{2}$ kullanılarak gerçekleştirilmiştir. Bu yöntemlerin etkinliği su buharı destilasyonu, geri soğutucu altında kaynatma ve ultrasonik banyoda organik çözücü ile ekstraksiyon yöntemleri kullanılarak kıyaslanmıştır. Ekstraktların antioksidan aktivitelerini belirlemek için serbest radikal temizleme yöntemi (DPPH), toplam antioksidan kapasite (CUPRAC) ve toplam fenol içeriği (FOLIN) yöntemleri uygulanmıştır. Sonuçlar ekstraktlardaki bileşen ve konsantrasyonların ekstraksiyon metoduna göre değişiklik gösterdiğini ortaya koymuştur. Bu farklılıktan yararlanarak ekstraktın kullanım amacına uygun ekstraksiyon metodu seçilebilir. Ekonomik olarak önemli olan oksijenli bileşenler en fazla sub-kritik su ekstraksiyonu ile elde edilmiştir. Antioksidan aktivite belirleme çalışmalarında en etkin yöntemin subkritik etil alkol ekstraksiyonu olduğu belirlenmiştir. Elde edilen sonuçların farmakoloji, gıda ve nutrasötik sektörlerine önemli katkı sağlayacağı düşünülmektedir.

Anahtar Kelimeler: Sub ve Süper kritik akışkanlar, Artemisia annua L., Antioksidan aktivite

\section{The Effect of Sub and Supercritical Fluids in Determination Chemical Composition and Antioxidant Capacity of Artemissia annua $\mathbf{L}$.}

\begin{abstract}
In this study, the effects of sub and supercritical fluid extraction methods on the chemical composition and antioxidant activity of annual wormwood (Artemisia annua L.) which is important medicinal aromatic plants were investigated. The applied sub/supercritical fluid extractions were subcritical water, subcritical ethanol and supercritical $\mathrm{CO}_{2}$. The efficiency of these methods has been compared by using steam distillation, refluxing and organic solvent extraction in an ultrasonic bath. Free radical scavenging method (DPPH), total antioxidant capacity (CUPRAC) and total phenol content (FOLIN) methods were conducted to determine the antioxidant activities of the extracts. The results revealed that the components and concentrations in the extracts varied according to the extraction method. Taking advantage of this difference, the extraction method suitable for the purpose of use of the extract can be selected.
\end{abstract}

*Sorumlu yazar (Corresponding author): Murat TÜRK, murturk@cu.edu.tr 

ve Süperkritik Akışkanların Etkisi

Economically important oxygenated components were mostly obtained by subcritical water extraction. It was determined that the most effective method in antioxidant activity determination studies was subcritical ethyl alcohol extraction. It is thought that the results obtained will make an important contribution to the pharmacology, food and nutraceuticals industries.

Keywords: Sub and Supercritical Fluids, Artemisia annua L, Antioxidant activity

\section{GİRiş}

Tıbbi bitkiler; modern ilaçlar, geleneksel ilaçlar, gıda katkıları, nutrosotikler, sentetik ilaçların kimyasal birimleri ve farmakolojik ara ürünler için en zengin biyolojik kaynaklardır. Aromatik bitkiler ise tat, koku, kozmetikler ve kimyasal terpenlerin kaynağıdır. Tıbbi ve aromatik bitkiler, gelişmiş ülkelerde olduğu gibi gelişmekte olan ülkelerde de basit yöntemlerden en ileri tekniklere kadar çeşitli yöntemlerle ekstrakte edilerek değerli bir biyo kaynağa dönüştürülebilmektedir[1].

Artemisia cinsinin üyeleri, en büyük ve yaygın olarak Compositae ailesine ait dağılmış türlerden biridir [2]. Y1llık pelinotu (Artemisia апnиа L.) ateş ve sıtma tedavisi için geleneksel Çin tıbbında kullanılan yıllık tıbbi bir bitkidir. Ayrıca yıllık pelinotu ekstraktları antimikrobiyal, antioksidan ve antiinflamatuar aktivitelerle ilişkili çeşitli biyomedikal ve farmakolojik uygulamalar sergilemektedir. Yıllık pelinotunun kimyasal bileşimi uçucu ve uçucu olmayan bileşenlerden oluşur. Uçucu olmayan ana bileşenler arasında seskiterpenoidler, flavonoidler ve kumarinler bulunur. $\mathrm{Bu}$ seskiterpenoidler arasında, yıllık pelinotunun yapraklarında ve çiçeklerinde bulunan artemisinindir (Şekil 1). Artemisinin yıllık pelinotunun temel biyoaktif bileşimini temsil eder ve bu türün sitma tedavisi aktivitesinden sorumludur [3].

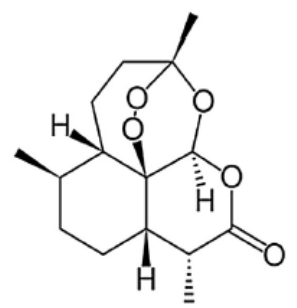

Şekil 1. Artemisinin kimyasal yapısı
Tıbbi ve aromatik bitkilerin endüstriyel olarak değerlendirilmesi; çeşitli teknikler kullanarak aktif bileşenlerinin ekstrakte edilmesiyle başlar. Bu amaçla kullanılan yaygın yöntemler; maserasyon (1slatma), demleme, sızdırma, parçalama, Soxhlet ekstraksiyonu, organik çözücülerle ekstraksiyon, mikrodalga yardımıyla ekstraksiyon, süperkritik akışkan ekstraksiyonu, ultrasonik ekstraksiyon ve hidroflorokarbon çözücülerle ekstraksiyondur. Aromatik bitkiler için hidro destilasyon (su, buhar ve su-buhar destilasyonları) ve sulu maserasyon en yaygın olarak uygulanan yöntemlerdir [1]. Çok daha yeni teknikler ise, katı-faz mikro ekstraksiyon, protoplast ekstraksiyon, mikrodestilasyon, termomikro destilasyon ve moleküler destilasyondur.

Tüm dünyada, bitkisel tıbbi ilaçlara, nutrosotiklere ve sağlık için doğal ürünlere gösterilen ilginin artmasıyla, tıbbi bitki ekstraktı üreticileri ve uçucu yağ üreticileri, ekstrakt ve uçucu yağ üretimi için belirli bir kaliteye sahip ve çalışma yapan her bir grubun birbirinden farklı sonuçlar vermeyeceği çok daha makul ekstraksiyon yöntemleri kullanmaya başlamışlardır[1]. Bu yaklaşımlar, hem artan kaliteli ürün isteğini karşılayabilmek hem de özellikle gelişmiş ülkelerde pazar sahibi olmak isteyen tıbbi aromatik bitkilerce zengin, gelişmekte olan ülkelerde kabul görmeye başlamıştır.

Uçucu yağlar, düşük konsantrasyonlarda bulunan kompleks karışımlardır. Bunların analiz edilmeden önce bulundukları matriksten uzaklaştırılması gerekir. Bu amaçla hidrodestilasyon, buhar destilasyonu Soxhlet ekstraksiyonu yaygin olarak kullanılır. Ancak uçucu yağları oluşturan moleküller isıl olarak hassas ve sicaklıkla kimyasal değişikliklere uğrayabilen bileşiklerdir. Bazı uçucu bileşenlerin kaybı, 1sıl ve hidrolitik etkilerle doymamış ve ester bileşiklerinin parçalanması ve ekstrakta zehirli çözücü kalıntısı, bu yöntemler kullanıldığında sık karşılaşılan dezavantajlardır. 
Bu dezavantajlar, uçucu yağ ektraksiyonunda yeni, daha az enerji daha az çözücü kullanılan, süperkritik akışkan ekstraksiyonu, ultrasonik ekstraksiyon ve mikrodalga ekstraksiyonu gibi "yeşil" tekniklerin gelişmesine neden olmuştur[1].

Süper kritik akışkan ekstraksiyonu, 20.yy'ın ikinci yarısında alternatif bir yöntem olmuştur. Bu alanda en yaygın kullanılan çözücü $\mathrm{CO}_{2}$ 'dir. Bunun en önemli sebepleri ise, çalışma sıcaklığının ve ekstraksiyon sürelerinin düşük olması ve dolayısıyla 1sıl olarak bozulabilecek doğal bileşenlerin zarar görmesinin engellenmiş olmasıdır. Özellikle 1980'lerden itibaren yapılan yoğun araştırmalar ile günümüzde süper kritik akışkanlarla ekstraksiyona ait tüm teknik ve ekonomik sorunlar yanıtlanmıştır. Süper kritik akışkan, aynı zamanda "yoğun gaz" olarak da tanımlanabilir. Sicaklığı kritik sıcaklığın üzerinde ve basıncı da kritik basincın üzerinde olan akışkanlardır. Bir akışkanın süper kritik akışkan olarak adlandırılması için indirgenmiş sıcaklığın $\operatorname{Tr}$ 1,2-1,3 arasında olmasi ( $\mathrm{Tr}=\mathrm{T} / \mathrm{Tc})$ gerekir. İndirgenmiş basınç $\mathrm{Pr}$ ise kullanılan sistemin teknik olarak elverdiği ölçüde olması yeterlidir (Pr=P/PC). Uygun koşullar sağlandığında herhangi bir sıvı süper kritik koşullarına ulaşabilir. Ancak sadece kritik sıcaklığı oda sıcaklığının çok üzerinde olmayan sıvılar, tıbbi aromatik bitkilerin ekstraksiyonunda alternatif bir çözücü olabilirler[4]. Karbon dioksit, düşük kritik sıcaklığı ve basıncı nedeniyle en çok uygulanan çözücü olmuştur $\left(\mathrm{T}_{\mathrm{C}}=31,06{ }^{\circ} \mathrm{C}\right.$ ve $\mathrm{P}_{\mathrm{C}}=73,81$ bar), süper kritik karbondioksit aynı zamanda toksik ve alev alıcı olmayışı, ucuz ve kolay temin edilebilir olması nedeniyle de alternatif bir çözücüdür. Ayrıca, süper kritik akışkanın yoğunluğu da önemli bir parametredir. Süper kritik akışkanların ekstraksiyon çözücüsü olabilmesi yoğunluğu ile doğrudan ilişkilidir. Chrastil, yoğunluk ve çözünürlük arasındaki ilişkiyi formül 1 de verildiği gibi ifade etmiştir [4].

$s=\rho^{\mathrm{a}} \exp (\mathrm{b} / \mathrm{T}+\mathrm{c})$

$s$ çözünürlük; $\rho$ çözücünün yoğunluğu; $T$ mutlak çalışma sıcaklığı; a, $b$ ve c düzeltme sabitleridir.

Bir akışkan kritik şartlara yaklaştıkça yoğunluğu bir sıvının yoğunluğuna yaklaşır. Şekil 2'de $\mathrm{CO}_{2}$ için yoğunluk izotermleri indirgenmiş basınca karşı grafiğe geçirilmiştir. Buradan $\mathrm{T}=35^{\circ} \mathrm{C}$ ve $\mathrm{P}=200$ bar da $\rho=866 \mathrm{~kg} / \mathrm{m}^{3}$ olduğu görülebilir. Çözücü yoğunluğu başarılı bir süper kritik akışkan ekstraksiyonunda anahtar faktördür.

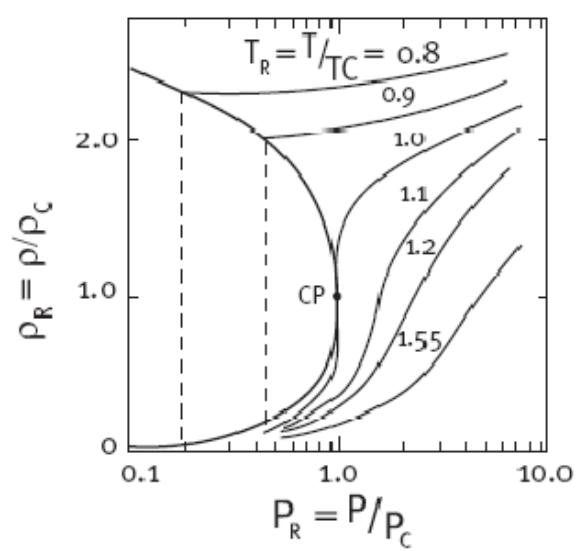

Şekil 2. $\mathrm{CO}_{2}$ için yoğunluk/basınç diyagramı

Sub- kritik su ise son birkaç yıl içinde çözücü olarak araştırmacılar tarafından kullanılmaya başlanmıştır.

Sub-kritik su ekstraksiyonu, $100-374{ }^{\circ} \mathrm{C}$ aralığında ve sıvı fazın oluşmasını sağlayacak bir basınçta suyun ektraksiyon çözücüsü olarak kullanıldığı bir yöntemdir. Bu koşullardaki su; pek çok organik molekül için iyi bir çözücü özelliğine sahip olması nedeniyle, bitki ekstraksiyonu için klasik ve süperkritik $\mathrm{CO}_{2}$ ekstraksiyonu yöntemlerine karş1 alternatif bir yöntem olarak gelecek vaat etmekte ve son yıllarda araştırmacılar tarafından artan bir ilgiyle kullanılmaktadır [5-6]. Sub-kritik su ekstraksiyonu, $100-374{ }^{\circ} \mathrm{C}$ aralığında ve sıvı fazın oluşmasını sağlayacak bir basınçta suyun ektraksiyon çözücüsü olarak kullanıldığg bir yöntemdir. Bu koşullardaki su; pek çok organik molekül için iyi bir çözücü özelliğine sahip olması nedeniyle, bitki ekstraksiyonu için klasik ve süperkritik $\mathrm{CO}_{2}$ ekstraksiyonu yöntemlerine karşı alternatif bir yöntem olarak gelecek vaat etmektedir [7-8].

Bunların yanı sıra etanol insanlar için nispeten toksik bir çözücü olmaması, suya göre düşük kritik 
Y1ll1k Pelinotunun (Artemissia annua L.) Kimyasal Kompozisyonu ve Antioksidan Kapasitesinin Belirlenmesinde Sub ve Süperkritik Akışkanların Etkisi

sıcaklığa sahip olması, polaritesinin $\mathrm{CO}_{2}$ 'de göre yüksek olması ve daha az korozif özellik göstermesi nedeniyle bitki ekstraksiyonunda alternatif olmaya adaydır [9].

Uçucu yağlar, gıda, farmakoloji ve parfüm endüstrisinde, koku ve tatları için kullanılan önemli doğal ürünlerdir. Özellikle enantiomerler ve yararlı kiral yapıtaşların sentezinde, aromatik kimyasalların da kaynağıdırlar. Son yıllarda uçucu yağların biyolojik ve farmakolojik aktiviteleri ve bileşenleri, artan bir şekilde bir ivme kazanmıştır. Uçucu yağların çoğu, hidrokarbonlar, esterler, terpenler, laktonlar, fenoller, aldehitler, asitler, alkoller ve ketonlardan oluşur. Bunların arasında oksijenli bileşenler (alkol, ester, aldehit, keton, lakton, fenol) ana koku kaynağıdırlar. Bu bileşenler oksitleyici ve reçineleşme etkilerine karşı diğer bileşenlere göre daha kararlıdırlar. Diğer taraftan, monoterpenler ve seskiterpenler gibi doymamış bileşenler hava ve 1 şık varlığında oksitlenme ve reçineleşme eğilimindedirler.

İnsan sağlığı açısından büyük risk oluşturan başta kanser olmak üzere kalp ve damar hastalıkları gibi pek çok hastalığın ortaya çıkma riskini azaltan veya olumlu etkiler gösteren antioksidanlar, günümüzde oldukça ilgi çeken ve üzerinde pek çok araştırmalar yapılan bir konudur. Vücutta çeşitli metabolik reaksiyonlar sonucu oluşan ve bir veya daha fazla eşleşmemiş elektronu olması sebebiyle oldukça reaktif olan serbest radikallerin aşırı miktarları (reaktif oksijen türleri üretiminin, tüketiminden fazla olması 'oksidatif stres' olarak adlandırılır) birçok doku, organ ve sistemlerde hasarlara neden olur. Ayrıca, bitki ekstraktlarının gida maddelerinin korunmasinda da kullanılabildiği bilinmektedir. Gıda maddelerinin işlenmesi, depolanması ve diğer işlemler sırasında lipidlerin oksidasyonu gida ürünlerinde bozunmalara neden olan işlemlerin başında gelir. Dolayısıyla bunların dayanıklılığını artırmak için sentetik antioksidanlar kullanılmaktadır. Doğal antioksidanlar, sentetik olan bütillenmiş hidroksi toluen (BHT) ve butillenmiş hidroksi anisol (BHA) bileşiklerinin kanserojenik oldukları şüpheleri nedeniyle doğal antioksidanlar tercih edilir hale gelmişlerdir [1].
Yapılan bir çalışmada, yıllık pelinotunda \%1,44,0 arasında farklı yapılarda uçucu yağ bulunduğu, uçucu yağında temel bileşenler olarak kamfor, artemisia keton, germakren d ve 1,8sineol'ün bulunduğu belirtilmektedir [10].

Juteau ve arkadaşları 2002 yılında yaptığı bir çalışmada, Artemisia annua nın uçucu kısımlarının kamfor (\%44), germakren D (\%16), transpinokarveol (\%11), $\beta$-selinen (\%9), $\alpha$-karyofilen (\%9) ve artemisia keton (\%3)'dan oluşan uçucu yağın antimikrobiyal aktifliğini incelemişlerdir. Uçucu yağın, test edilen gram-pozitif bakteri Enterococcus hirae'nin ve tüm test mantarının gelişimini belirgin bir şekilde engellediğini tespit etmişlerdir. Bu uçucu yağ referans bileşiği \%18'lik $\alpha$-tocopherole eşdeğer bir antioksidan aktifliği gösterdiğini belirlemişlerdir [11].

Tzenkova ve arkadaşlarının yaptığı bir çalışmada, Bulgaristan'da yabani olarak yetişen Artemisia annua'nın uçucu yağı hidrodestilasyon ile elde etmişler ve GC/MS ile analiz etmişlerdir. Ana bileşenleri $\alpha$-karyofillene (\%24,73), $\alpha$-kuveben $(\% 13,53), \alpha$-kopaen $(\% 7,42), \beta$-selinene $(\% 8,21)$, artemisia keton $(\% 8,45)$ ve kamfor $(\% 3,61)$ olarak belirlemişlerdir. Uçucu yağ bileşenlerinin diğer coğrafi bölgelerde yetişenlerden farklı olduğunu gözlemişlerdir [12].

2017 yılında yapılan bir başka çalışmada, yıllık pelinotu, süper kritik karbon dioksit ile ekstrakte edildikten sonra, kalan atık kısımdan fenolik bileşenler, su veya etanol gibi çözücülerle ikinci bir ektraksiyon ile elde edildiği bildirilmiştir. Birinci basamakta yüksek verimle artemisin elde edildiğini ve sıtma tedavisinde etki gösterdiğini belirtmişlerdir. Atık kısmın ikinci ekstraksiyonunda artemisin bulunmamasina rağmen yüksek fenol içeriğe sahip olduğunu saptamışlar ve yüksek antioksidan kapasite gösterdiğini rapor etmişlerdir [3].

$\mathrm{Bu}$ çalışmada, tıbbi özelliklere sahip olan yıllık pelinotu (Artemisia annua L.) bitkisinin kimyasal kompozisyonu ve antioksidan aktivitesi üzerine sub ve süperkritik akışkan ekstraksiyon metodlarının etkileri incelenmiştir. Uygulanan 
sub/süperkritik akışkan ekstraksiyonları, subkritik su, subkritik etanol ve süperkritik $\mathrm{CO}_{2}$ kullanılarak gerçekleştirilmiştir. $\mathrm{Bu}$ yöntemler su buharı destilasyonu, geri soğutucu altında kaynatma ve ultrasonik banyoda organik çözücü ile ekstraksiyon yöntemleri ile karşılaştırılmıştır. Ekstraktlara uygulanan antioksidan aktivite belirleme metodları olarak, serbest radikal temizleme yöntemi (DPPH), toplam antioksidan kapasitesi (CUPRAC) ve toplam fenol içeriği (FOLIN) yöntemleri kullanılmıştır. Belirlenen antioksidan kapasiteye göre en etkin bitki ekstraktı ve bir bitki için en yüksek antioksidan aktivite gösteren ekstraksiyon metodu değerlendirilmesi yapılmıştır. Ekstraksiyon verimi, biyolojik aktivite, bir bileşenin en fazla miktarda olması istenen bir kompozisyon gibi amaca uygun bir ekstraksiyon metodunun seçilebileceği bir çalışma amaçlanmıştır.

\section{MATERYAL VE METOT}

\subsection{Materyal}

\subsubsection{Bitki Kaynağı}

Denemelerde kullanılan y1llık pelin otu (Artemisia annua L.), Çukurova Üniversitesi Ziraat Fakültesi Tarla Bitkileri araştırma alanında yetiştirilmiştir. Y1llık pelinotunun bitkinin toprak üstü kısımları saf su ile yıkandıktan sonra oda koşullarında karanlıkta 2 hafta boyunca kurutulmuştur. Kurutulmuş örnekler, 5 mm'lik iç çapa sahip huni boynundan geçecek şekilde elle ögüutülmüştür. Kurutulmuş ve ögütülmüş bitki örnekleri, analizden önce plastik şişelerde buzdolabında $4{ }^{\circ} \mathrm{C}$ de saklanmıştır.

\subsubsection{Kimyasallar}

Hekzan, diklorometan, etanol, metanol, DPPH, terbutil metileter, sodyum hidroksit, aseton, neokuprin, sodyum klorür, Amonyum asetat, Bakır(II) klorür, $\mathrm{BF}_{3}$-metanol (\%10-15 w/v), Folin-Ciocalteu reaktifi, troloks ve gallik asit (Merck-Sigma-Aldrich analitik saflıkta), $\mathrm{CO}_{2(\mathrm{~s})}$ (Linde \% 99,9999), C18 kartuş (Agilent marka).

\subsection{Metot}

\subsubsection{Süper Kritik $\mathrm{CO}_{2}$ Yöntemiyle $\left(\mathrm{skCO}_{2} \mathrm{E}\right)$ Bitki Ekstraktlarının Hazırlanması}

Ekstraksiyonlar Çukurova Üniversitesi FenEdebiyat Fakültesi Kimya Bölümü Organik Kimya Araştırma Laboratuvarında oluşturulan sistemin kullanılmasıyla gerçekleştirilmiştir (Şekil 3). Çalışmada kullanılan parametreler ve aralıkları ön denemeler yapılarak Çizelge 1'de verilmiştir. Ekstraksiyon hücresi 2,0 g örnekle doldurulduktan sonra istenilen ekstraksiyon sıcaklığında çalışmak için fırın içine yerleştirilmiştir. Bir ISCO pompası yardımıyla istenilen basınçta süper kritik $\mathrm{CO}_{2}$ hücreye gönderilerek, $30 \mathrm{dk}$ statik ve $20 \mathrm{dk}$ dinamik ekstraksiyon gerçekleştirilmiştir. Ekstrakte edilen bileşenleri toplamak için, yaklaşık $2 \mathrm{~mL} \mathrm{dk}{ }^{-1}$ akış hızında bir restriktör (Suprex marka) ile içinde diklorometan bulunan bir tüpte toplanmıştır.

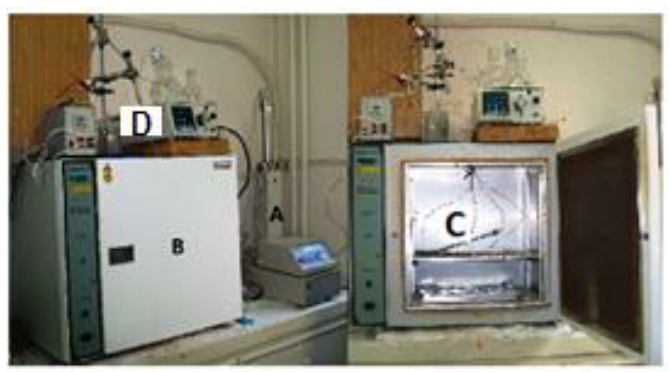

Şekil 3. Süper kritik akışkan ekstraksiyon sistemi, A: ISCO pompa; B: Fırın C: Ekstrasiyon hücresi; D: HPLC pompas1

\subsubsection{Sub-Kritik Su (sbkH $\left.\mathrm{H}_{2} \mathrm{OE}\right)$ Yöntemiyle Bitki Ekstraktlarının Hazırlanması}

Ekstraksiyon hücresi 2,0 gram örnekle doldurulduktan sonra istenilen ekstraksiyon sıcaklığında çalışmak için fırın içine yerleştirilmiştir. Bir HPLC pompası yardımıyla istenilen basınçta gazı giderilmiş deiyonize su, 2 $\mathrm{mL} / \mathrm{dk}$ akış hızında hücreye gönderilmiştir. $30 \mathrm{dk}$ süreyle statik ekstraksiyon ve ardından $20 \mathrm{dk}$ dinamik ekstraksiyonla örnek toplanmıştır. (Şekil 3). Kullanılan parametreler ve aralıkları ön denemeler yapılarak Çalışma koşulları, Çizelge 1. de verilmiştir. Uçucu yağlar bir kez $5 \mathrm{~mL}$ 
Y1ll1k Pelinotunun (Artemissia annua L.) Kimyasal Kompozisyonu ve Antioksidan Kapasitesinin Belirlenmesinde Sub ve Süperkritik Akışkanların Etkisi

diklorometan ile sıv1-sıv1 ekstraksiyon yapılarak alınmıştır.

\subsubsection{Sub-Kritik $\mathrm{Su}\left(\mathrm{sbkH}_{2} \mathrm{OE}\right)$ Yöntemiyle Bitki Ekstraktlarının Hazırlanması}

Ekstraksiyon hücresi 2,0 gram örnekle doldurulduktan sonra fırın içine yerleştirilmiştir. Çizelge 1'de verilen çalışma koşullarında, bir HPLC pompası yardımıyla, istenilen basınçta gazı giderilmiş etanol $2 \mathrm{~mL} / \mathrm{dk}$ akış hızında hücreye gönderilmiştir. $30 \mathrm{dk}$ süreyle statik ekstraksiyon ve ardından $20 \mathrm{dk}$ dinamik ekstraksiyonla örnek toplanmıştır (Şekil 3).

Çizelge 1. Yillık pelinotunun sub ve süperkritik akışkanlarla ekstraksiyon için çalışma koșulları

\begin{tabular}{|l|c|c|c|c|}
\hline Çözücü & $\begin{array}{c}\mathrm{T} \\
\left({ }^{\mathrm{O}} \mathrm{C}\right)\end{array}$ & $\begin{array}{c}\mathrm{P} \\
(\mathrm{atm})\end{array}$ & $\begin{array}{c}\text { Akış Hızı } \\
(\mathrm{ml} / \mathrm{dk})\end{array}$ & Zaman (dk) \\
\hline skCO & 40 & 300 & 2 & 20 (statik), 30 (dinamik) \\
\hline $\mathrm{H}_{2} \mathrm{O}$ & 125 & 80 & 2 & 30 (statik), 20 (dinamik) \\
\hline EtOH & 125 & 80 & 2 & 30 (statik), 20 (dinamik) \\
\hline
\end{tabular}

\subsubsection{Su Buharı Destilasyonu ile Bitki Ekstraksiyonu (SBD)}

Pelinotunun üst kısımlarımdan alınan $50 \quad \mathrm{~g}$ kurutulmuş örnek Neo-clevenger aparatında su buharı destilasyonu yöntemi ile 3 saat süreyle ekstrakte edilmiştir. Ekstraksiyon sonunda sulu fazdan uçucu yağların kuru olarak alınması katı faz ekstraksiyon sistemiyle yapılmıştır.

\subsubsection{Ultrasonik Banyoda Organik Çözücülerle Bitki Ekstraksiyonu (USE)}

2,0 gram pelinotu örneği $30 \mathrm{~mL}$ ter-butil metil eter ile oda sicaklığında ultrasonik banyoda 2 saat süreyle ekstrakte edilmiştir. Ekstraksiyon sonunda ekstrakt ve artık $10000 \mathrm{rpm}$ de $30 \mathrm{dk}$ santrifüj edildikten sonra ekstrakt Whatman 4 nolu süzgeç kağıdı ile süzülerek alınmıştır.

\subsubsection{Organik Çözücülerle Geri Soğutucu Altında Kaynatma ile Bitki Ekstraksiyonu (GSK)}

2 gram bitki örneği $30 \mathrm{~mL} \quad(1: 1 \quad \mathrm{v} / \mathrm{v})$ diklorometan:aseton çözücü karışımı ile karışımın kaynama sıcaklığında 3 saat süreyle geri soğutucu altında kaynatılarak ekstrakte edilmiştir. Ekstraksiyon sonunda ekstrakt ve artık $10000 \mathrm{rpm}$ de $30 \mathrm{dk}$ santrifüj edildikten sonra ekstrakt Whatman 4 nolu süzgeç kağıdı ile süzülerek alınmıştır.

\subsubsection{Katı Faz Ekstraksiyonu}

Bu çalışmada C18 kartuş kullanılmıştır. Kolon yıkama ve şartlama işleminde metanol-su (1:1) karışımı kullanılmıştır. Örnek toplama işlemide çözücü olarak hekzan kullanılmıştır [13].

\subsubsection{Kromatografik Ayırma ve Tanımlama}

Tüm deneylerden elde edilen ekstraktların GC-MS analizleri Termo-Finnigan Trace marka kütle spektrometresinde elektron impakt $(70 \mathrm{eV})$ ile yapılmıştır. Kromatografik ayırma TR-MS-5 (60m x 0,25 mm x 0,25 $\mu \mathrm{m}, \% 5$ fenil polisiloksan), kolonda gerçekleştirilmiştir. Sicaklık programı $50{ }^{\circ} \mathrm{C}$ de 1 dakika bekletilir. $3{ }^{\circ} \mathrm{C} / \mathrm{dk}$ isitma hizıyla $160{ }^{\circ} \mathrm{C}$ ye çıkarılır, burada 3 dakika bekletildikten sonra $5{ }^{\circ} \mathrm{C} / \mathrm{dk}$ isıtma hızıyla $250{ }^{\circ} \mathrm{C}$ 'ye çıkarılır ve burada 10 dakika bekletilir. Enjeksiyon sicaklığ $240{ }^{\circ} \mathrm{C}$ ve split10 modunda çalışılmıştır. Analizlerde helyum taşıyıcı gaz olarak kullanıldı ve akış hızı 1,0 mL dk ${ }^{-1}$ olarak belirlendi. GC-MS analizlerinde enjeksiyon işlemi bir otosampler yardımıyla yapılmıştır. Her bir bileşen, kütle spektrumlarının Wiley07 ve NIST(2005) kütüphanesinden yararlanılarak karşılaştırma ve $\mathrm{C}_{9}-\mathrm{C}_{20} \mathrm{n}$ - alkanlar kullanılarak Kovat İndislerinde hesaplanmasıyla tanımlanmıştır.

\subsubsection{Kovat İndislerinin Hesaplanması}

İsotermal olmayan Kovats İndisi (sıcaklık programı için Van den Dool ve Kratz'ın eşitliği kullanılarak) hesaplanmıştır [14] (Eşitlik 1).

$\mathrm{Ix}=100 \mathrm{n}+100(\mathrm{tx}-\mathrm{tn}) /(\mathrm{tn}+1-\mathrm{tn})$

Eşitlikte, Ix; " $X$ " kimyasal bileşeni için Kovat indisi, tn ve $t n+1$, kimyasal bileşik " $X$ " ten hemen önce ve sonra ayrilan referans n-alkan hidrokarbonlarının alıkonma sürelerini 
göstermektedir. Formülde tx ise " $\mathrm{X}$ " bileşiğinin alıkonma süresidir.

\subsubsection{DPPH Yöntemi}

DPPH yöntemi, antioksidanların kararlı bir organik azot radikali olan DPPH $(1,1-$ difenil2pikrilhidrazil) radikalini giderici etkilerini ölçmeye dayalı bir yöntemdir. Bu radikal hidrojen donörlerle etkileştiğinde hidrazine indirgenir. Kırmızı renkli DPPH radikali 515 nm'de maksimum absorbsiyon verir. DPPH çözeltisine antioksidanın ilave edilmesiyle absorbansta düşüş meydana gelir ve antioksidanların varlığıyla radikalin rengi kırmızıdan sarıya döner. Bu yöntem antioksidanların radikal giderici kabiliyetlerini değerlendiren kolay ve geçerli bir yöntem olarak bilinmektedir [15].

Miliauskas ve arkadaşları tarafından bildirilen DPPH metodunda laboratuvarımızda çok az değişiklik yapılarak kullanılmıştır. Değişik konsantrasyonlarda $(2,5 \mathrm{mg}$ ekstrakt/ml metil alkol; $1: 5 ; 1 ; 10$ oranında seyreltilmiş) 100 mikrolitre ekstrakta, 3,9 ml metanolde çözülmüş $0,06 \mathrm{mM}$ DPPH çözeltisi eklendi. Örnekler çalkalandıktan sonra oda koşullarında karanlıkta 20 dakika bekletildi ve 517 nm'de absorbans ölçülmüştür. \% DPPH radikal temizleme aktivitesi aşağıdaki formül kullanılarak hesaplanmıştır (Eşitlik 2).

$\%$ İnhibisyon $=[($ Kontrol Absorbans-Örnek Absorbans)/Kontrol Absorbans]x100

$\% 50$ radikal temizleme aktivitesine karşılık gelen derişim (\%50 inhibisyon) $\mathrm{I}_{50}$ olarak ifade edilmiştir [16].

\subsubsection{CUPRAC(Cupric Reducing Antioxidant Capacity; $\mathrm{Cu}(\mathrm{II})$ İyonu İndirgen Antioksidan Kapasitesi) Yöntemi ile Toplam Antioksidan Aktivite Ölçülmesi}

Çözeltilerin Hazırlanması: $10^{-2} \mathrm{M}$ Bakır(II)klorür çözeltisi, $0,4262 \mathrm{~g} \mathrm{CuCl}{ }_{2} \cdot 2 \mathrm{H}_{2} \mathrm{O} 250 \mathrm{ml}$ suda çözülerek hazırlanmıştır. pH 7,0 Amonyum asetat tampon çözeltisi, $19,27 \mathrm{~g} \mathrm{NH} \mathrm{NH}_{4} \mathrm{Ac} 250 \mathrm{ml}$ suda çözülerek hazırlanmıştır. $7,5 \times 10^{-3} \mathrm{M}$ Neokuprin çözeltisi, 0,039 g Neokuprin $25 \mathrm{ml} \% 96$ 'lı etil alkolde çözülerek hazırlanmıştır.

CUPRAC Yöntemi: Test tüpüne Bakır(II) Klorür çözeltisi, Neokuprin çözeltisi ve $\mathrm{NH}_{4} \mathrm{AC}$ tampon çözeltisinden 1'er ml eklendi. Antioksidan örnek çözeltisinden $(2,5 \mathrm{mg} / \mathrm{ml})$ (veya standart çözeltiden) $0,1 \mathrm{ml}$ eklendikten sonra $1 \mathrm{ml} \mathrm{H}_{2} \mathrm{O}$ eklenerek toplam hacim 4,1 ml'ye tamamland. 1 saat sonra 450 nm'de köre karşı absorbans ölçümleri kaydedilmiştir. Standart (troloks) kalibrasyon eğrisi konsantrasyona karşı absorbans olarak çizilmiştir ve sonuçlar eşdeğer troloks olarak ifade edilmiştir [17].

\subsubsection{Folin Ciocalteu Yöntemi ile Toplam Fenol İçerik Tayini (FOLIN)}

$1 \mathrm{ml}$ 1:10 seyreltilmiş Folin-Ciocalteu reaktifi üzerine 100 mikrolitre $(2,5 \mathrm{mg} / \mathrm{ml})$ ekstrakt eklendi. 4 dakika sonra 800 mikrolitre sodyum karbonat çözeltisi (75 g/L) eklendi. 2 saat oda koşullarında bekletildikten sonra 765 nm'de absorbansları ölçülmüştür. Standart kalibrasyon eğrisi gallik asit $(0-500 \mathrm{mg} / \mathrm{L})$ kullanılarak çizilmiştir. Sonuçlar eşdeğer gallik asit olarak ifade edilmiştir [18-19].

\section{BULGULAR VE TARTIŞMA}

$\mathrm{Bu}$ çalışmada tıbbi aromatik bitkilerden biri olan yıllık pelinotunun (Artemisia annua L.) kimyasal kompozisyonu ve antioksidan aktivitesi üzerine ekstraksiyon metotlarının etkisi incelenmiştir.

Sub ve süperkritik akışkan ekstraksiyonunda kullanılan koşullar, temel bileşenlerin yüksek göreceli bolluğuna göre belirlenmiş olup, Çizelge 3'de özetlenmiştir. $\mathrm{SBD}$ ve $\mathrm{sbkH}_{2} \mathrm{OE}$ yöntemleri ile hazırlanan uçucu yağlar ile GSK, USE, $\mathrm{skCO}_{2} \mathrm{E}$ ve sbkEtOHE yöntemleri ile hazırlanan ekstraktların ekstraksiyon verimleri Çizelge 2'de verilmiştir. Yukarda anılan yöntemlerle elde edilen ekstrakların organik bileşenleri Çizelge 3'de verilmiştir. Çizelgelerde de göreceli miktarı \%0,1'den az olan bileşenlere yer verilmemiştir. Ekstraktlara ait GC-MS kromatogramları ise Şekil 4'de verilmiştir. 
Y1llık Pelinotunun (Artemissia annua L.) Kimyasal Kompozisyonu ve Antioksidan Kapasitesinin Belirlenmesinde Sub ve Süperkritik Akışkanların Etkisi

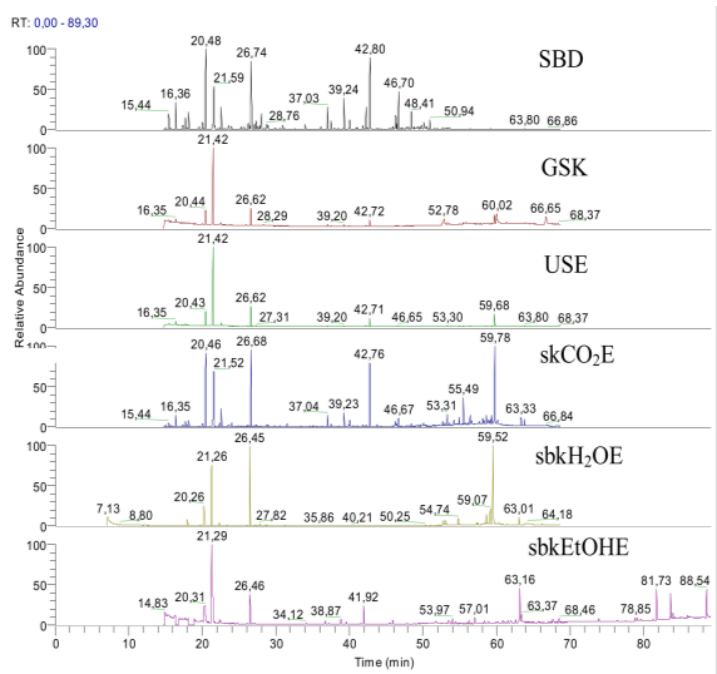

Şekil 4. Yillık pelinotunun SBD, GSK, USE, $\mathrm{skCO}_{2} \mathrm{E}, \quad \mathrm{sbkH}_{2} \mathrm{OE}$ ve sbkEtOHE ekstraksiyon yöntemleriyle, elde edilen uçucu yağların kromato gramları

Ekstraksiyon metoduna göre ekstraksiyon verimleri değerlendirildiğinde; sbkEtOH yöntemiyle hazırlanan ekstraktın en yüksek ekstrakt verimine $(\% 18,1)$ sahip olduğu gözlenmiştir (Çizelge 2).

Çizelge 2. Y1llık Pelinotunun ekstraksiyon metoduna göre hazırlanan ekstraktlarının ekstraksiyon verimleri

\begin{tabular}{|l|c|}
\hline & Ylllk pelinotu \\
\hline Yöntem & \% Verim (w/w) \\
\hline sbkH ${ }_{2} \mathrm{OE}$ & 1,2 \\
\hline skCO $_{2} \mathrm{E}$ & 6,5 \\
\hline sbkEtOH & 18,1 \\
\hline SBD & 2,5 \\
\hline GSK & 7,1 \\
\hline USE & 6,9 \\
\hline
\end{tabular}

\subsection{Yıllık Pelinotu ile Yapılan Ekstraksiyonlar}

Ylllk Pelinotundan GSK, USE, skCO $\mathrm{SO}_{2} \mathrm{E}$, ve sbkEtOHE yöntemleri ile elde edilen ekstraktlar ve $\mathrm{SBD}, \mathrm{sbkH}_{2} \mathrm{OE}$ ile hazırlanan uçucu yağın GC-MS analiz sonuçları Çizelge 3'de ve GC-MS kromatogramları ise Şekil 4'de verilmiştir. $\mathrm{sbkH}_{2} \mathrm{OE}$ ile ekstraksiyon sirasinda en etkin çalışma koşullarının $125^{\circ} \mathrm{C}$ sıcaklık, 80 atm basınç ve dakikada $2 \mathrm{ml}$ akıș hızı olduğu belirlenmiștir (Çizelge 1). Yıllık pelinotudan $\mathrm{sbkH}_{2} \mathrm{OE}$ ile elde edilen uçucu yağın verimi $\% 1,2 \mathrm{w} / \mathrm{w}$ 'dir ve GC-MS analizinde ise 133 sinyal tespit edilmiştir (Çizelge 2 ve 3).

sbkH $_{2} \mathrm{OE}$ ile hazırlanan uçucu yağda temel bileşenler sırasıyla bisiklik seskiterpen olan arteannuin b (artemisin) (\%25,5), bisiklik monoterpen olan kamfor $(\% 20,1)$, düzensiz bir monoterpen olan artemisya keton $(\% 17,2)$, bir bisiklik monoterpen eter olan 1,8 - sineol $(\% 5,5)$ ve bir seskiterpen lakton olan qinghaosu $(\% 2,1)$ 'dur. $\mathrm{sbkH}_{2} \mathrm{OE}$ yöntemiyle hazırlanan uçucu yağın $\% 0,2$ 'sini monoterpen bileşikleri, \%45,3'ünü oksijenli monoterpen bileşikleri ve \%36,5'ini oksijenli seskiterpen bileşiklerinin oluşturduğu belirlenmiştir.

Y1llık pelinotunun $\mathrm{skCO}_{2} \mathrm{E}$ ile ekstraksiyonunda en uygun çalışma koşullarının $40{ }^{\circ} \mathrm{C}$ sicaklık ve $300 \mathrm{~atm}$ basınç olduğu belirlenmiştir Çizelge 1 . Bu koşullarda elde edilen ekstraktın verimi \%6,5'dir ve GC-MS analizinde ise 262 sinyal tespit edilmiştir (Çizelge 2 ve 3). $\mathrm{skCO}_{2} \mathrm{E}$ ile hazırlanan uçucu yağda temel bileşenler sırasılyla artemisya keton $(\% 11,7)$, arteannuin $\mathrm{b}$ (artemisin) $(\% 11,6)$, kamfor $(\% 11,0)$, 1,8- sineol $(\% 8,5)$, bisiklik seskiterpen olan $\beta$-selinen $(\% 7,6)$, çok yönlü seskiterpen olan karyofillen $(\% 1,6)$ ve bisiklik monoterpen olan kamfen $(\% 1,6)$ 'dir. $\mathrm{skCO}_{2} \mathrm{E}$ yöntemiyle hazırlanan uçucu yağın \%4,7'sini monoterpen bileşikleri, \%37,7'sini oksijenli monoterpen bileşikleri \%13,2'sını seskiterpen bileşikleri ve \%17,4'sini oksijenli seskiterpen bileşiklerinin oluşturduğu belirlenmiş̧ir.

sbkEtOHE ile yıllık pelinotundan elde edilen ekstraktın verimi \%18,1 w/w'dir ve bu verim $125{ }^{\circ} \mathrm{C}$ sıcaklık ve $80 \mathrm{~atm}$ basınç uygulandığında gözlenmiştir (Çizelge 1). GC-MS analiz sonuçlarına göre 79 sinyal tespit edilmiştir (Çizelge 2 ve 3 ). sbkEtOHE ile hazırlanan ekstraktta temel bileşenler sirasıyla artemisya keton $(\% 28,5)$, arteannuin b (artemisin) $(\% 8,2)$, 1,8-sineol $(\% 7,6)$, kamfor $(\% 7,5), 31$ karbonlu düz zincirli alkan olan hentriakontan $(\% 7,9), 30$ karbonlu dallanmış alkan olan squalen (\%6,4), 30 karbonlu düz zincirli alkan olan triakontan $(\% 6,1)$ 
ve $\beta$-selinen $(\% 3,3)$ 'dir. sbkEtOHE yöntemiyle hazırlanan uçucu yağın \%0,4'ünü monoterpen bileşikleri, \%45,3'ünü oksijenli monoterpen bileşikleri \%6,0'ını seskiterpen bileşikleri, $\% 13,8$ 'ini oksijenli seskiterpen bileşikleri ve \%20,4'ünü uzun zincirli hidrokarbon bileşiklerinin oluşturduğu belirlenmiştir.

SBD ile y1llık pelinotundan elde edilen uçucu yağın verimi \%2,5 w/w'dir ve GC-MS kromatogramında 234 sinyal tespit edilmiştir (Çizelge 1,2 ve 3). SBD ile hazırlanan uçucu yağda temel bileşenler sırasıyla kamfor $(\% 13,2)$, artemisya keton (\% 11,4), 1,8-sineol (\%10,2), $\beta$-selinen $(\% 9,4)$, karyofillen $(\% 3,3)$ ve karyofillen oksit $(3,8)$ olarak saptanmıştır. SBD yöntemiyle hazırlanan uçucu yağın \%8,6'sını monoterpen bileşikleri, \%47,3'ünü oksijenli monoterpen bileşikleri, \%21,1'ini seskiterpen bileşikleri ve $\% 12,7$ 'sini oksijenli seskiterpen bileşiklerinin oluşturduğu belirlenmiştir.

GSK ile yıllık pelinotundan elde edilen ekstraktın verimi \% 7,1 w/w'dir ve GC-MS kromatogramında 62 sinyal belirlenmiştir (Çizelge 1, 2 ve 3 ). GSK yöntemiyle hazırlanan uçucu yağda temel bileşenler sırasıyla artemisya keton (\%43,7), kamfor $(\% 9,9)$, 1,8-sineol $(\% 7,1)$, arteannuin b (artemisin) $(\% 5,6), \quad \beta$-selinen $(\% 4,3)$, kamfen $(\% 1,9)$ ve karyofillen $(\% 1,3)$ olarak bulunmuştur. GSK yöntemiyle hazırlanan uçucu yağın \%5,1'ini monoterpen bileşikleri, \%63,6'sını oksijenli monoterpen bileşikleri, \%7,6'sını seskiterpen bileşikleri ve \%9,3'ünü oksijenli seskiterpen bileşiklerinin oluşturduğu belirlenmiştir.

USE ile yıllık pelinotundan elde edilen ekstraktın verimi \%6,9 w/w'dir ve GC-MS analizinde ise 75 sinyal tespit edilmiştir (Çizelge 2 ve 3 ). USE ile hazırlanan uçucu yağda temel bileşenler sırasıyla artemisya keton (\%42,6), kamfor (\%12,2), 1,8-sineol (\%9,0), arteannuin b (artemisin) $(\% 6,8), \quad \beta$-selinen $(\% 5,2)$ kamfen $(\% 2,5)$ ve karyofillen $(\% 1,2)$ 'dir. USE yöntemiyle hazırlanan uçucu yağın \%7,2'sini monoterpen bileşikleri, \%67,6'sın1 oksijenli monoterpen bileşikleri $\% 8,3$ 'ünü seskiterpen bileşikleri ve \%10,9'unu oksijenli seskiterpen bileşiklerinin oluşturduğu belirlenmiştir.

Çizelge 3. Yıllık pelinotunun (Artemisia annua L.) ekstraksiyon metoduna göre kimyasal kompozisyonu

\begin{tabular}{|c|c|c|c|c|c|c|c|}
\hline KI & Bileșen & \multicolumn{6}{|c|}{ Göreceli Dağılım (\%) } \\
\hline & & $\mathrm{sbkH}_{2} \mathrm{OE}$ & $\mathrm{skCO}_{2} \mathrm{E}$ & sbkEtOHE & SBD & GSK & USE \\
\hline 934 & $\alpha$-thujen & $\ldots$ & $\mathbf{0 , 5}$ & $\ldots$ & $\mathbf{0 , 3}$ & $\ldots$ & $\ldots$ \\
\hline 941 & $\alpha$-pinen & --- & 0,6 & --- & 1,8 & 1,0 & 1,3 \\
\hline 957 & kamfen & $\begin{array}{ll}-- \\
\end{array}$ & 1,6 & --- & 2,9 & 2,0 & 2,5 \\
\hline 973 & Sabinen & --- & 0,3 & --- & 0,5 & 0,7 & 0,8 \\
\hline 980 & $\beta$-pinen & --- & 0,7 & --- & 1,3 & 0,7 & 1,1 \\
\hline 983 & $\beta$-mirsen & --- & 0,2 & --- & 0,3 & 0,2 & 0,3 \\
\hline 986 & yomogi alkol & 1,6 & 0,7 & --- & 2,0 & 0,6 & 0,8 \\
\hline 1016 & $\alpha$-humulen & $\ldots$ & 0,1 & --- & 0,3 & --- & 0,2 \\
\hline 1029 & p-simen & 0,2 & 0,6 & 0,4 & 1,1 & 0,3 & 0,5 \\
\hline 1034 & dl-limonen & --- & --- & --- & 0,1 & --- & 0,1 \\
\hline 1042 & 1,8-sineol & 5,5 & 8,5 & 7,6 & 10,2 & 7,1 & 9,0 \\
\hline 1072 & artemisia keton & 17,2 & 11,7 & 28,5 & 11,4 & 43,7 & 42,6 \\
\hline 1073 & $\gamma$-terpinen & --- & 0,2 & --- & --- & 0,2 & 0,4 \\
\hline 1093 & trans-sabinene hidrat & --- & 0,4 & 0,2 & 0,2 & 0,4 & 0,3 \\
\hline 1098 & $\begin{array}{c}\text { 3,3,6-trimetil-1,5- } \\
\text { heptadien-4-ol }\end{array}$ & 0,9 & 2,0 & 1,1 & 2,3 & 1,6 & 1,8 \\
\hline 1119 & E-farnesen epoksit & 0,2 & 0,2 & --- & 0,4 & --- & 0,2 \\
\hline 1128 & $\begin{array}{c}\text { 5-isopropyl-2- } \\
\text { metilbisiklo[3.1.0]hexan- }\end{array}$ & ... & 0,6 & 0,2 & 0,3 & 0,3 & 0,4 \\
\hline 1146 & 2-metil-3-penten-1-ol & 0,1 & 0,2 & & . & $\ldots$ & $\cdots$ \\
\hline
\end{tabular}


Y1ll1k Pelinotunun (Artemissia annua L.) Kimyasal Kompozisyonu ve Antioksidan Kapasitesinin Belirlenmesinde Sub ve Süperkritik Akışkanların Etkisi

Çizelge 3 (devam)

\begin{tabular}{|c|c|c|c|c|c|c|c|}
\hline 1155 & $\alpha$-kamfolenal & --- & 0,1 & --- & 0,4 & --- & --- \\
\hline 1162 & $\begin{array}{l}\text { 2-metil-6-metilen-1,7- } \\
\text { oktadien-3-on }\end{array}$ & $\cdots$ & 0,1 & $\cdots$ & 0,3 & $\cdots$ & $\cdots$ \\
\hline 1173 & pinokarveol & 0,3 & 0,4 & --- & 0,9 & --- & 0,2 \\
\hline 1178 & $\begin{array}{c}\text { 2,6-dimetil-1,5,7- } \\
\text { oktatrien-3-ol }\end{array}$ & $\cdots$ & 0,1 & $\cdots$ & 0,3 & $\cdots$ & $\cdots$ \\
\hline 1183 & kamphor & 20,1 & 11,0 & 7,5 & 13,2 & 9,9 & 12,2 \\
\hline 1189 & cis-verbenol & --- & 0,2 & --- & 0,5 & --- & --- \\
\hline 1195 & 2(10)-pinen-3-on & 0,2 & 0,3 & --- & 0,7 & 0,2 & 0,3 \\
\hline 1200 & p-menth-1-en-8-ol & 0,1 & 0,2 & --- & 0,3 & --- & --- \\
\hline 1205 & borneol & --- & 0,13 & --- & 0,6 & --- & --- \\
\hline 1211 & p-menth-1-en-4-ol & 0,5 & 0,2 & --- & 1,5 & --- & 0,1 \\
\hline 1227 & linalil propionat & 0,2 & 0,5 & --- & 1,0 & --- & 0,2 \\
\hline 1232 & mirtenal & 0,2 & 0,2 & --- & 0,3 & --- & 0,2 \\
\hline 1268 & cis-karveol & $\ldots$ & 0,2 & $\ldots$ & 0,2 & $\ldots$ & $\ldots$ \\
\hline 1355 & $\mathrm{C}_{10} \mathrm{H}_{20} \mathrm{O}$ & $\ldots$ & 0,1 & 0,2 & $\ldots$ & $\ldots$ & $\ldots$ \\
\hline 1386 & eugenol & 0,1 & --- & --- & 0,3 & --- & --- \\
\hline 1405 & $\alpha$-kopaen & --- & 1,2 & 0,5 & 2,1 & $\mathbf{0 , 9}$ & 0,9 \\
\hline 1413 & benzil 2-metilbutanoat & $\begin{array}{ll}-- \\
\end{array}$ & 0,4 & 0,2 & 1,1 & 0,3 & 0,4 \\
\hline 1432 & $\beta$-kopaen- $4 \alpha$-ol & 0,1 & $\ldots$ & $\ldots$ & 0,2 & $\ldots$ & $\ldots$ \\
\hline 1447 & karyofillen & --- & 1,6 & --- & 3,3 & 1,3 & 1,2 \\
\hline 1463 & $\beta$-farnesen & --- & 0,8 & 0,5 & 1,3 & 0,4 & 0,5 \\
\hline 1482 & $\alpha$-karyofillene & --- & 0,1 & --- & 0,2 & --- & --- \\
\hline 1496 & $\alpha$-himakalen & --- & 0,3 & 0,3 & 0,6 & +-- & $\begin{array}{ll}-- \\
\end{array}$ \\
\hline 1508 & germakren-d & --- & 0,4 & 0,7 & 2,4 & 0,7 & 0,6 \\
\hline 1523 & $\beta$-selinen & --- & 7,6 & 3,3 & 9,4 & 4,3 & 5,2 \\
\hline 1548 & $\delta$-kadinen & --- & 0,4 & --- & 0,2 & --- & --- \\
\hline 1555 & $\mathrm{C}_{15} \mathrm{H}_{24} \mathrm{O}$ & $\ldots$ & 0,1 & $\ldots$ & 0,1 & $\ldots$ & $\ldots$ \\
\hline 1564 & $\mathrm{C}_{14} \mathrm{H}_{22} \mathrm{O}$ & $\ldots$ & 0,1 & 0,1 & 0,1 & $\ldots$ & $\ldots$ \\
\hline 1604 & $\mathrm{C}_{15} \mathrm{H}_{24}$ & $\ldots$ & 0,1 & $\ldots$ & 0,3 & $\ldots$ & $\ldots$ \\
\hline 1611 & tanımlanamad1 & $\ldots$ & 0,7 & $\ldots$ & 2,0 & 0,2 & 0,2 \\
\hline 1612 & $\mathrm{C}_{15} \mathrm{H}_{24} \mathrm{O}$ & $\ldots$ & 0,6 & 0,2 & $\ldots$ & $\ldots$ & 0,2 \\
\hline 1618 & karyofillen oksit & --- & 0,9 & --- & 3,8 & 0,7 & 0,6 \\
\hline 1634 & $\alpha$-bisabolen epoxide & --- & 0,2 & --- & 0,6 & --- & --- \\
\hline 1645 & kubenol & --- & 0,6 & 0,8 & 1,9 & --- & 0,2 \\
\hline 1672 & $\mathrm{C}_{15} \mathrm{H}_{24} \mathrm{O}$ & 0,1 & 0,5 & 0,9 & 1,0 & 0,1 & 0,2 \\
\hline 1678 & isoaromadendren & 0,1 & 0,2 & 1,0 & 0,4 & --- & --- \\
\hline 1721 & $\mathrm{C}_{15} \mathrm{H}_{24} \mathrm{O}$ & 1,2 & 1,2 & --- & 0,2 & 0,8 & 0,8 \\
\hline 1724 & $\mathrm{C}_{14} \mathrm{H}_{22} \mathrm{O}$ & 0,3 & 0,4 & 1,1 & 0,2 & 0,2 & 0,1 \\
\hline 1751 & arteannuik asit & 0,2 & 0,2 & --- & --- & --- & --- \\
\hline 1754 & $\mathrm{C}_{15} \mathrm{H}_{26} \mathrm{O}_{2}$ & 0,1 & 0,1 & 0,5 & --- & --- & --- \\
\hline 1756 & tanımlanamad1 & 1,6 & 0,7 & 0,1 & --- & 0,3 & 0,3 \\
\hline 1772 & $\mathrm{C}_{15} \mathrm{H}_{24} \mathrm{O}$ & 0,3 & 0,2 & --- & --- & --- & --- \\
\hline 1778 & tanımlanamadı & 0,2 & 2,6 & 0,2 & --- & 0,8 & 0,7 \\
\hline 1797 & sedran-8-13-diol & 0,2 & 0,9 & 0,2 & --- & 0,3 & 0,3 \\
\hline 1800 & $\mathrm{C}_{15} \mathrm{H}_{24} \mathrm{O}$ & $\ldots$ & 0,4 & --- & --- & 0,3 & 0,3 \\
\hline 1827 & tanımlanamadı & 0,7 & 0,3 & 0,2 & --- & --- & --- \\
\hline 1838 & $\mathrm{C}_{15} \mathrm{H}_{20} \mathrm{O}_{2}$ & 0,3 & 0,5 & 0,5 & --- & 0,2 & 0,2 \\
\hline 1850 & iso-velleral & 0,6 & 1,0 & 0,6 & --- & 0,3 & 0,3 \\
\hline 1857 & tanımlanamadı & 3,2 & 0,7 & --- & --- & --- & --- \\
\hline
\end{tabular}


Çizelge 3 (devam)

\begin{tabular}{|c|c|c|c|c|c|c|c|}
\hline 1863 & heneikosan & 0,2 & 0,3 & 0,8 & --- & 0,3 & 0,2 \\
\hline 1867 & deoksiginghaosu & 3,4 & 0,8 & --- & --- & 0,3 & 0,3 \\
\hline $\mathbf{1 8 7 7}$ & arteannuin b (artemisin) & $\mathbf{2 5 , 5}$ & $\mathbf{1 1 , 6}$ & $\mathbf{8 , 2}$ & --- & $\mathbf{5 , 6}$ & $\mathbf{6 , 8}$ \\
\hline 1885 & tetrakosan & 0,7 & 0,1 & --- & --- & 4,5 & --- \\
\hline 1945 & Qinghaosu & 2,1 & --- & --- & --- & --- & --- \\
\hline 1952 & $\mathrm{C}_{14} \mathrm{H}_{22} \mathrm{O}_{2}$ & $\ldots$ & 1,1 & --- & --- & 0,4 & 0,4 \\
\hline 1961 & heptakosan & & & & & & \\
\hline 2015 & nonakosan & --- & 0,3 & --- & --- & 2,6 & --- \\
\hline 2102 & squalen & --- & --- & 6,4 & --- & --- & --- \\
\hline 2127 & triakontan & --- & --- & 6,1 & --- & --- & --- \\
\hline 2131 & tanimlanamad1 & --- & --- & 1,2 & --- & --- & --- \\
\hline 2193 & hentriacontan & --- & --- & 7,7 & --- & --- & --- \\
\hline \multicolumn{2}{|c|}{ TOPLAM GERI KAZANIM } & 88,5 & 82,5 & 88 & 87,3 & 94,7 & 96,4 \\
\hline
\end{tabular}

Çizelge 3'den de görüldüğü gibi yıllık pelinotundan elde edilen uçucu yağlarda belirlenen bileşenlerin göreceli dağılımı (\%) seçilen ekstraksiyon metoduna göre farklılık göstermektedir.

Genel olarak $\alpha$-tujen, $\alpha$-pinen, kamfen, sabinen, $\beta$-pinen ve $\beta$-mirsen gibi monoterpen bileşiklerine sbkH $\mathrm{H}_{2} \mathrm{OE}$ ve sbkEtOHE ekstraktlarında hiç rastlanmamıştır. Artemisya keton, kamfor, 1,8 sineol, $\beta$-selinen ve arteannuin b (artemisin) bileşikleri tüm yöntemlerde hazırlanan uçucu yağlarda belirlenmiştir. Ancak, artemisya keton göreceli olarak en fazla \%43,7 ile GSK yönteminde gözlenirken, kamfor göreceli olarak en fazla $(\% 20,1) \quad$ sbkH $_{2} \mathrm{OE}$ yönteminde, 1,8-sineol göreceli olarak en fazla $(\% 10,2)$ SBD yönteminde, $\beta$-selinen göreceli olarak en fazla $(\% 9,4)$ SBD yönteminde ve arteannuin $b$ (artemisin) göreceli olarak en fazla $(\% 25,5)$ sbkH$_{2} \mathrm{OE}$ yönteminde gözlenmiştir.

Altı farklı ekstraksiyon ile yıllık pelinotundan elde edilen ekstraktlarda oksijenli monoterpen bileşikleri göreceli olarak en fazla USE ekstraksiyonunda elde edilirken, seskiterpen bileşikleri göreceli olarak en fazla SBD ekstraksiyonunda elde edilmiştir. Oksijenli seskiterpen bileşikleri ise göreceli olarak en fazla $\mathrm{sbkH}_{2} \mathrm{OE}$ yönteminde elde edilmiştir. Diğer yöntemlerden farklı olarak sbkEtOHE yönteminde uçucu yağların yanı sıra uzun zincirli hidrokarbonlar da elde edilmiştir.
Literatürde yer alan bir çalışmada yıllık pelinotunu hidrodestilasyon ekstraksiyonu ile ekstrakte etmişler. Ekstraksiyon sonucunda temel bileşenleri kamfor $\quad(\% 44,0)$ germakren $(\% 16,0)$, trans-pinokarveol $(\% 11,0), \quad \beta$-selinen $(\% 9,0)$, $\beta$-karyofillen $(\% 9,0)$ ve artemisya keton $(\% 3,0)$ olarak belirlemişlerdir [11]. Literatürde yer alan bir diğer çalışmada Bulgaristan'da yetiştirilen yıllık pelinotunu hidrodestilasyon ekstraksiyonu ile ekstrakte etmişler. Ekstraksiyon sonucunda GC-MS analiz sonuçlarına göre temel bileşenleri $\alpha$-karyofillen $\quad(\% 24,7), \quad \alpha$-kuveben $\quad(\% 13,5)$, $\alpha$-kopaen $(\% 7,4), \alpha$-selinen $(\% 8,2)$, artemisya keton $(\% 8,5)$ ve kamfor $(\%, 3,6)$ olarak belirlemişlerdir [12].

Literatürde yer alan çalışmalarda ve bizim çalışmamızdan elde edilen uçucu yağ bileşenleri aynı olmakla beraber göreceli dağılımları farklıdır. $\mathrm{Bu}$ da bitkilerin farklı coğrafyalardan yetiştirilmiş olmasından kaynaklanmaktadır.

\subsection{Yıllık Pelinotundan Elde Edilen Uçucu Yağ ve Ekstraktların Antioksidan Aktiviteleri}

\subsubsection{DPPH Yöntemi}

Y1llık pelinotunun su buharı destilasyonu ile ekstraksiyonu sonucu elde edilen ekstraktın DPPH yöntemi ile antioksidan aktivitesi ölçülmüştür. SBD ekstraksiyonu ile elde edilen ekstraktın, Şekil 5'de verilen grafikten, $\mathrm{I}_{50}$ değeri 1167,2 mg bitki/ml olarak bulunmuştur. 
Y1ll1k Pelinotunun (Artemissia annua L.) Kimyasal Kompozisyonu ve Antioksidan Kapasitesinin Belirlenmesinde Sub ve Süperkritik Akışkanların Etkisi

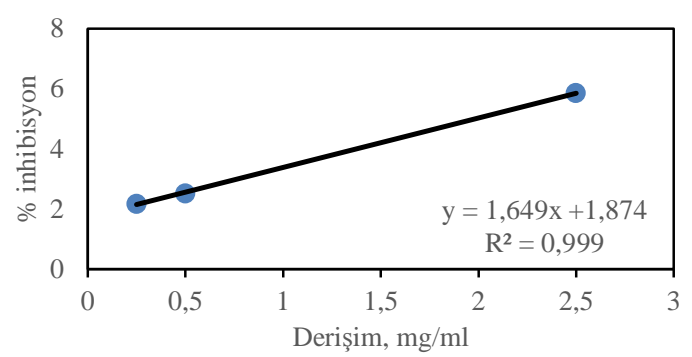

Şekil 5. Yillık pelinotunun SBD ekstraksiyonu ile elde edilen ekstraktın derişim-\% inhibisyon grafiği

Y1llık pelinotunun geri soğutucu altında çözücü ile kaynatma (GSK) sonucu elde edilen ekstraktın DPPH yöntemi ile antioksidan aktivitesi ölçüldüğünde, $\mathrm{I}_{50}$ değeri $227,3 \mathrm{mg}$ bitki $/ \mathrm{ml}$ olarak bulunmuştur (Şekil 6).

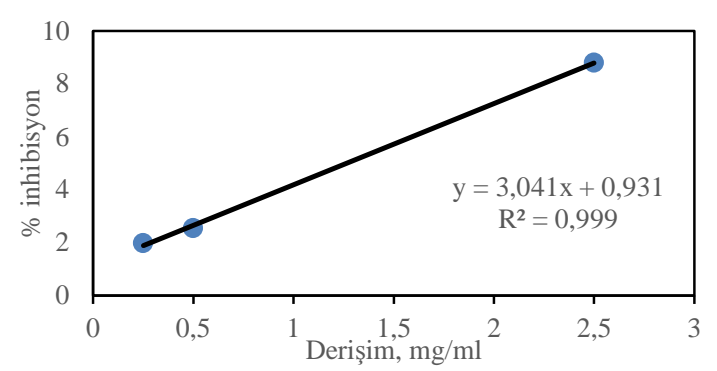

Şekil 6. Y1llık pelinotunun GSK ekstraksiyonu ile elde edilen ekstraktın derişim-\% inhibisyon grafiği

Ylllı pelinotunun ultrasonik banyoda ekstraksiyonu (USE) sonucu elde edilen ekstraktın DPPH yöntemi ile antioksidan aktivitesi ölçüldüğünde (Şekil $\quad 7$ ) $\mathrm{I}_{50}$ değeri $\quad 138,0 \quad \mathrm{mg}$ bitki/ml olarak bulunmuştur.

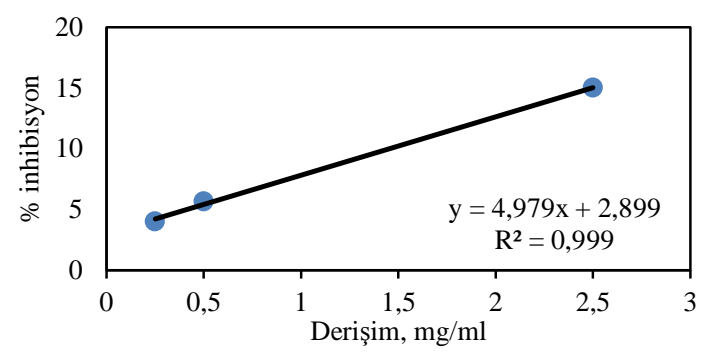

Şekil 7. Yillık pelinotunun USE ekstraksiyonu ile elde edilen ekstraktın derişim-\% inhibisyon grafiği
Sub kritik su ekstraksiyonu ( $\mathrm{sbkH}_{2} \mathrm{OE}$ ) sonucu elde edilen yıllık pelinotu ekstraktın $\mathrm{I}_{50}$ değeri $510,8 \mathrm{mg}$ bitki/ml olarak bulunmuştur (Şekil 8).

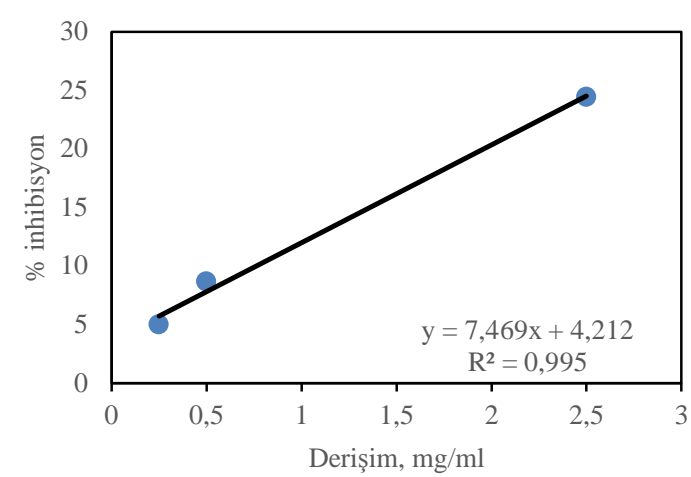

Şekil 8. Yıllık pelinotunun $\mathrm{sbkH}_{2} \mathrm{OE}$ yöntemi ile elde edilen ekstraktın derişim-\% inhibisyon grafiği

Y1llk pelinotunun sub kritik etil alkol ekstraksiyonu (sbkEtOHE) sonucu elde edilen ekstraktın DPPH yöntemi ile antioksidan aktivitesi Şekil 9'da verilen grafikten, $I_{50}$ değeri $24,4 \mathrm{mg}$ bitki/ml olarak bulunmuştur.

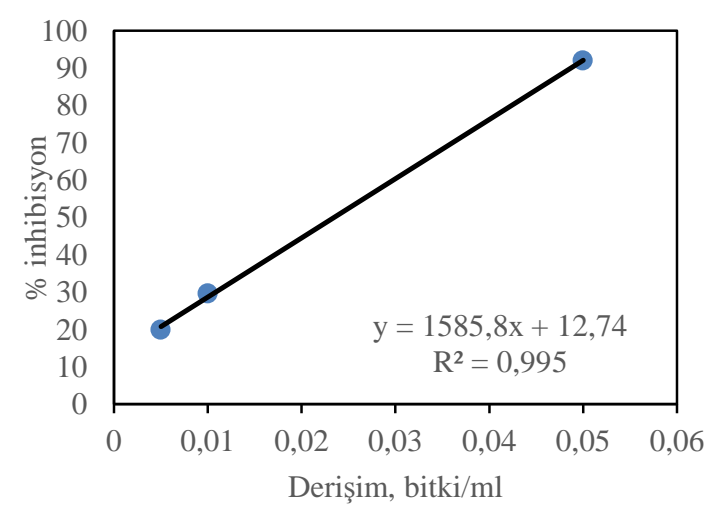

Şekil 9. Y1llık pelinotunun sbkEtOHE ekstraksiyonu ile elde edilen ekstraktın derişim-\% inhibisyon grafiği

Y1llı pelinotunun süper kritik $\mathrm{CO}_{2}$ ekstraksiyonu $\left(\mathrm{skCO}_{2} \mathrm{E}\right)$ sonucu elde edilen ekstraktın DPPH yöntemi ile antioksidan aktivitesi ölçülmüştür. Şekil 10'da verilen grafikten, $\mathrm{I}_{50}$ değeri $4488,0 \mathrm{mg}$ bitki/ml olarak bulunmuştur. 


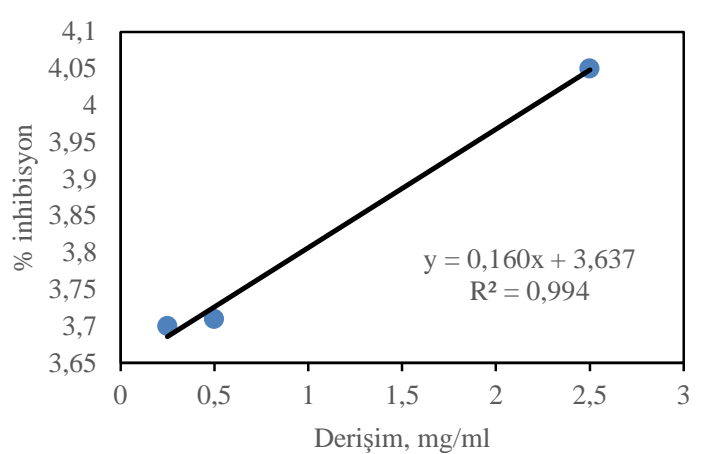

Şekil 10. Yıllık pelinotunun

$\mathrm{skCO}_{2} \mathrm{E}$ ekstraksiyonu ile elde edilen ekstraktın Derişim-\% inhibisyon grafiği

\begin{tabular}{|c|c|}
\hline Yöntem & $\mathrm{I}_{50} \mathrm{mg}$ bitki/ml \\
\hline sbkH $_{2} \mathrm{OE}$ & 510,8 \\
\hline $\mathrm{skCO}_{2} \mathrm{E}$ & 4458,0 \\
\hline sbkEtOHE & 24,4 \\
\hline $\mathrm{SBD}$ & 1167,2 \\
\hline $\mathrm{GSK}$ & 227,3 \\
\hline USE & 138,0 \\
\hline BHT & $1,55 \mathrm{mg} \mathrm{BHT} / \mathrm{ml}$ \\
\hline
\end{tabular}

Çizelge 4. Yıllık pelinotunun altı farklı yöntemle elde edilen ekstraktlarının ve sentetik antioksidan BHT'nin DPPH yöntemi ile $\mathrm{I}_{50}$ değerleri

Yıllık pelinotu için radikal temizleme aktivitesine göre yöntemleri büyükten küçüğe sıralayacak olursak sbkEtOHE $>\mathrm{USE}>\mathrm{GSK}>\mathrm{sbkH}_{2} \mathrm{OE}>\mathrm{SBD}$ $>\mathrm{skCO}_{2} \mathrm{E}$ şeklinde sıralanmaktadır.

\subsubsection{CUPRAC Yöntemi}

Y1ll1k pelinotunun elde edilen altı farklı ekstraktlarının CUPRAC yöntemi ile toplam antioksidan aktiviteleri belirlenmiştir. Sonuçlar Şekil 11'de verilen kalibrasyon eğrisinden yararlanılarak hesaplamıştır. Yıllık pelinotu için CUPRAC yöntemine göre antioksidan aktiviteleri Çizelge 5.'de verilmiştir. Yıllık pelinotu için CUPRAC yöntemine göre antioksidan aktivitelerini yöntemlere göre büyükten küçüğe siralayacak olursak sbkEtOHE >USE $>$ GSK $>$
$\mathrm{skCO}_{2} \mathrm{E}>\mathrm{sbkH}_{2} \mathrm{OE}>\mathrm{SBD}$ şeklinde sıralanmaktadır. Sonuçlar DPPH yöntemiyle karşılaştırıldığında, benzer sonuçlar elde edildiği saptanmıştır.

Çizelge 5. Yıllık pelinotu ekstraktlarının CUPRAC yöntemi ile toplam antioksidan aktiviteleri

\begin{tabular}{|c|c|}
\hline Yöntem & $\mathrm{mg}$ troloks/g bitki \\
\hline $\mathrm{sbkH}_{2} \mathrm{OE}$ & 2,3 \\
\hline $\mathrm{skCO}_{2} \mathrm{E}$ & 3,2 \\
\hline $\mathrm{sbkEtOHE}$ & 41,4 \\
\hline $\mathrm{SBD}$ & 1,0 \\
\hline $\mathrm{GSK}$ & 3,8 \\
\hline USE & 7,9 \\
\hline BHT & $1270,40 \mathrm{mg}$ TR/g BHT \\
\hline
\end{tabular}

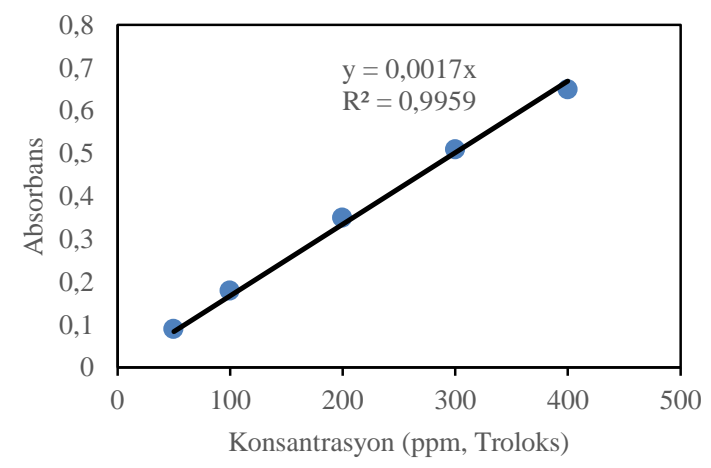

Şekil 11. Yıllık pelinotu ekstraktlarının CUPRAC yöntemiyle toplam antioksidan değerlerini belirlenmesi için standart troloks kalibrasyon eğrisi

\subsubsection{Folin Ciocalteu Yöntemi (FOLIN)}

Folin Ciocalteu yöntemi ile yıllık pelinotunun ekstraklarının toplam fenol içerikleri belirlenmiştir. Sonuçlar Şekil 12 'de verilen kalibrasyon eğrisinden yararlanılarak hesaplanmıştır. Elde edilen ekstraktların fenol içerikleri Çizelge 6'da gösterilmiştir. Çizelge 6'dan da görüleceği gibi sbkEtOHE yöntemiyle elde edilen ekstraktının diğer yöntemlerle elde edilen ekstraktlara göre yüksek fenol içeriğine sahip olduğu görülmektedir. Sonuçlar, CUPRAC yöntemi ve DPPH yöntemiyle elde edilen sonuçlarla benzerlik göstermektedir. 
Y1llık Pelinotunun (Artemissia annua L.) Kimyasal Kompozisyonu ve Antioksidan Kapasitesinin Belirlenmesinde Sub ve Süperkritik Akışkanların Etkisi

Çizelge 6. Y1llık pelinotu ekstraktlarının Folin Ciocalteu yöntemi ile toplam fenol içeriklerinin belirlenmesi

\begin{tabular}{|l|c|}
\hline Yöntem & mg GA/g bitki \\
\hline sbkH $_{2} \mathrm{OE}$ & 0,7 \\
\hline skCO $\mathrm{C}_{2} \mathrm{E}$ & 0,9 \\
\hline sbkEtOHE & 9,0 \\
\hline SBD & 0,5 \\
\hline GSK & 1,1 \\
\hline USE & 2,6 \\
\hline
\end{tabular}

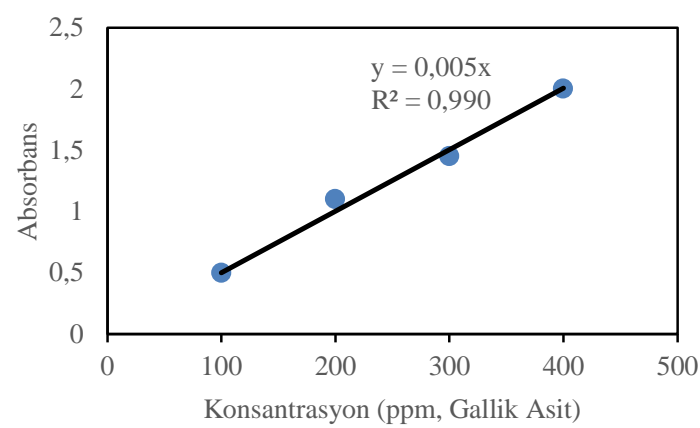

Sekil 12. Yıllık pelinotu ekstraktlarının toplam fenol içeriklerinin belirlenmesi için standart gallik asit kalibrasyon eğrisi

\section{SONUÇLAR}

\subsection{Sonuçlar ve Öneriler}

i) $\mathrm{sbkH}_{2} \mathrm{OE}$ yöntemiyle elde edilen ekstraktın uçucu yağ kalitesinin diğer yöntemlerle elde edilen yağlardan daha iyi olması, ekstraksiyonun hızlı bir şekilde tamamlanması, göreceli olarak düşük sıcaklıklarda çalıșlarak, sıcaklıkla bozunan bileşenlerin kaybının önlemesi, göreceli olarak düşük maliyetli olması, basit olması ve çevresel açıdan elverişli olması gibi özellikleri ile diğer yöntemlere güçlü alternatif bir yöntem olduğu belirlenmiştir. Antioksidan aktivitesi açısından değerlendirildiğinde sbkEtOHE ekstraksiyon metodunun güçlü bir yöntem olduğu görülmektedir. Bileşen konsantrasyonları ekstraksiyon metoduna göre değişiklik göstermesi nedeniyle; ekstraktın kullanım amacına uygun (gıda, kozmetik, ilaç vb.) bir ekstraksiyon metodunun seçilebilmesinin mümkün olduğu belirlenmiştir.

ii) Ekstraksiyon metoduna göre farklılık gösteren bileşenler amaca göre ekstrakte edildikten sonra ayırma ve saflaştırma teknikleri ile saf olarak elde edilebilir ve karakterize edilebilir.

iii) Sub ve süper kritik akışkan ekstraksiyon için belirlenen optimum koşullarda sürekli bir ekstraksiyon sistemi ile çalışılabilir.

iv) Elde edilen ekstraktlara mikrokapsülleme uygulamaları çalışılabilir.

v) $\mathrm{sbkH}_{2} \mathrm{OE}$ ve $\mathrm{SBD}$ ile ekstraksiyonda uçucu yağ elde edildikten sonra kalan sulu kısımdaki bileşenleri belirleme çalışmaları sıv1 kromatografisi ile (HPLC, LC-MS, vb.) yürütülebilir.

\section{TEŞEKKÜR}

$\mathrm{Bu}$ çalışmada Çukurova Üniversitesi Bilimsel Araştırma Koordinasyonu Birimi tarafından desteklenmiştir (Proje numarası: FEF2006D19).

Bu çalışmada yıllık pelinotunu temin edilmesini sağlayan, Ç.Ü. Ziraat Fakültesi Tarla Bitkileri Bölümü Öğretim Üyelerinden sayın Prof. Dr. Saliha KIRICI'ya teşekkür ederiz.

\section{KAYNAKLAR}

1. Türk, M., 2010. Bazı Önemli Tıbbi Bitkilerin Kimyasal Kompozisyonu ve Antioksidan Kapasitelerinin Belirlenmesinde Sub ve Süperkritik Akışkanların Etkisi, Ç.Ü. Doktora Tezi, Fen Bilimleri Enstitüsü.

2. Altunkaya, A., Yıldırım, B., Ekici, K., Terzioğlu, Ö., 2014. Determining Essential Oil Composition, Antibacterial and Antioxidant Activity of Water Wormwood Extracts, GIDA, 39(1), 17-24.

3. Martinez-Correa, A.H., Bitencourt G., Raphaela, Kayano, A.V.A.C., Magalhales, M.P., Costa, T.M.F., Cabral, A.F., 2017. Integrated Extraction Process to Obtain Bioactive Extracts of Artemisia Апnиa L. 
Leaves Using Supercritical $\mathrm{CO}_{2}$, Ethanol and Water, Industrial Crops and Products, 95, 535-542.

4. Chrastil, J., 1982. Solubility of Solids and Liquids in Supercritical Gases, Journal of Physical Chemistry, 86, 3016-3021.

5. Giray, E. S., Kırıcı, S., Kaya, D. A., Türk, M., Sönmez, Ö., İnan, M., 2008. Comparing the Effect of Subcritical Water Extraction with Conventional Extraction Methods on the Chemical Composition of Lavandula Stoechas. Talanta, 74, 930-935.

6. Özel, Z.M., Gogus, F., Lewis, C.A., 2003. Subcritical Water Extraction of Essential Oils from Thymbra Spicata, Food Chemistry, 82, 381-386.

7. Gracia, G.L., Castro, L.D.M., 2000. Continuous Subcritical Water Extraction of Medicinal Plant Essential Oil: Comparison with Conventional Techniques, Talanta, 51, 1179-1185.

8. Kubatova, A., Miller, J.D., Hawthorne, B.S., 2001. Comparison of Subcritical Water and Organic Solvents for Extracting Kava Lactones from Kava Root, Journal of Chromatography A, 923, 187-194.

9. Wang, Y., Gao, Y., Ding, H., Liu, S., Han, X., Gui, J., Liu, D., 2017. Subcritical Ethanol Extraction of Flavonoids from Moringa Oleifera Leaf and Evaluation of Antioxidant Activity, Food Chemistry, 218, 152-158.

10. Mohammadreza, R.V., 2008. Variation in the Essential Oil Composition of Artemisia annua L. of Different Growth Stages Cultivated in Iran, Botany Research Journal, 1(2), 33-35.

11. Juteau, F., Masotti, V., Bessiere, M.J., Dherbomez, M., Viano, J., 2002. Antibacterial and Antioxidant Activities of Artemisia Annua Essential Oil, Fitoterapia, 73, 532-535.

12. Tzenkova, R., Kamenarska, Z., Draganov, A., Atanassov, A., 2010. Composition of Artemisia Annua Essential Oil Obtained From Species Growing Wild In Bulgaria, Biotechnol \& Biotechnol. Eq., 24(2), 1833- 1835.

13. Beney, P.J., Breuer, G.M., Jacobs, G.H., Zierath, D.L., Mollenhauer, P.J., Norton, K.K., 1996. Review, Evaluation, and Application of Solid Phase Extraction Methods, Hygienic
Laboratory, University of Iowa, 102 Oakdale Campus, Iowa City, Iowa, 52242-500.

14. http://webbook.nist.gov/chemistry/gc-ri/

15. Sanchez, M. C., Larraurı, J.A., Saura, C.F., 1998. A Procedure to Measure the Antiradical Efficiency of Polyphenols, Journal of the Science of Food and Agriculture, 76, 270-276.

16. Miliauskas, G., Venskutonis, R. P., Beek, van T.A., 2004. Screening of Radical Scavenging Activity of Some Medicinal and Aromatic Plant Extracts, Food Chemistry, 85, 231-237.

17. Apak, R., Güçlü, K., Özyürek, M., Karademir, E.S.,. 2004. Novel Total Antioxidant Capacity Index for Dietary Polyphenols and Vitamins C and E, Using Their Cupric Ion Reducing Capability in the Presence of Neocuproine: CUPRAC Method, Journal of Agricultural and Food Chemistry, 52, 7970-7981.

18. Singleton, V.L., Rossi, J.A., 1965. Colorimetry of Total Phenolics with PhosphomolybdicPhosphotungstic Acid Reagents, American Journal of Enology and Viticulture, 16, 144-158.

19. Singleton, V.L., Orthofer, R., LamuelaRaventos, R.M., 1999. Analysis of Total Phenols and Other Oxidation Substrates and Antioxidants by means of Folin-Ciocalteu Reagent, Methods in Enzymolology, 299, 152-178.

20. Wong, M., Li, B.H., Cheng, K.W., Chen, F., 2006. A Systematic Survey of Antioxidant Activity of 30 Chinese Medicinal Plants Using the Ferric Reducing Antioxidant Power Assay, Food Chemistry, 97, 705-7011. 
